cloisons étanches dans l'univers. James Dauphiné démontre comment les structures temporelles du voyage correspondent aux structures spatiales, comment la "science, poésie et mythologie se confortent, se répondent."'Dante est astrologue, théologien, mystique mais surtout poète, poète-voyant. C'est ainsi qu'on le surprend à sacrifier l'exactitude scientifique au souci d'équilibre poétique.

La quatrième partie est la plus ambitieuse, la plus personnelle. Il s'agit de montrer Dante aux prises avec l'écriture: la Divine Comédie n'est pas une oeuvre didactique. En plus d'être une oeuvre mystique, c'est une oeuvre d'art. James Dauphiné parle d'aventure stylistique: Dante doit révéler l'extraordinaire, l'inconnaissable, Dieu, au moyen des mots. Cet extraordinaire, Dante l'a vu tant avec son oeil physique que son oeil spirituel et il est ébloui au sens fort du mot. James Dauphiné, après Pézard (Dante sous la pluie de feu), Tuzet (l'imagination stellaire de Dante et le Cosmos et l'imagination), fait de la divine Comédie une épopée de la lumière. Sous la protection de différents guides, dont évidemment Béatrice, Dante passe de l'absence de lumière à l'éblouissement total au paradis où la lumière est intensifiée, magnifiée grâce à des jeux de miroirs. L'auteur veut traiter de "la nature lumineuse de l'univers et les aspects de ce dernier en relation avec la thématique du nombre, du cercle et de la musique" en s'attachant particulièrement aux images, métaphores, symboles et allégories. Il expose clairement, avec autorité, le système poétique de Dante. On peut toutefois regretter des longueurs, des répétitions. Surtout il aurait fallu que James Dauphiné fût poète luimême pour pouvoir faire ressortir la poésie de la divine Comédie. En effet, à l'issue de cette étude et malgré les protestations de l'auteur, on est amené à voir le poème davantage comme un oeuvre initiatique que comme une oeuvre lyrique.

Malgré ces quelques réserves, le livre de James Dauphiné, le Cosmos de Dante est un compagnon indispensable à tout étudiant non seulement de Dante mais de toute poésie cosmologique occidentale.

\title{
SIMONE MASER, Unviersité d'Ottawa
}

Jenny Wormald. Court, Kirk, and Community: Scotland 1470-1625. University of Toronto Press: Toronto and Buffalo, 1981. Pp. viii, 216.

This recent work on the history of early modern Scotland covers the period from the reign of James III through that of James VI. Quite naturally a focal point of this book is the age of the Scottish reformation, a topic covered in four well-organized chapters. This central section dealing with a time of religious uncertainty is presented between two surveys of Renaissance Scotland.

The author provides a well-balanced account of early modern Scotland, and her analysis makes effective use of recent scholarly studies that give new insights into the complexities of internal developments in the country during an especially critical period of its history. Of the Scottish rulers of that time high praise is accorded to James VI. He is commended for his intelligence, his forceful foreign policy, and his resolute refusal to be brow-beaten by Elizabeth 1 . As the author points out, he did much to enhance the prestige of personal monarchy.

Scotland's history during the age of the Renaissance and Reformation is charac- 


\section{8 / Renaissance and Reformation}

terized by the vitality and variety of its political, religious, and cultural experience. These diverse aspects are clearly delineated by the author. The book's value is further enhanced by seven and a half pages devoted to suggestions for further reading, and by a chronological table of five pages. There is also a serviceable idex. This study is an important and valuable one which provides a thoughtful basis for a reconsideration of Scottish history during one of the more colourful periods of its long history.

\section{BERNARD C. WEBER, The University of Alabama}

Hallet Smith. The Tension of the Lyre: Poetry in Shakespeare's Sonnets. San Marino, CA: Huntington Library, 1981. Pp. xii, 172 pp.

Hallet Smith's Elizabethan Poetry (1952) is a readable and economical study still worth recommending as a judicious introduction to Tudor poetry for students just beginning their studies. The same cannot be said, unfortunately, of The Tension of the Lyre which is intended "to make the sonnets more accessible to various kinds of readers" (p. ix). While this latest study is readable, brief, and full of interesting observations on various aspects of the sonnets, it does not offer its "various kinds of readers" much that is new or vitally interesting.

The first of six chapters begins with a discussion of T.S. Eliot's "Three Voices of Poetry" (1953): the first is the voice of the poet "talking to himself-or to nobody. The second is the voice of the poet addressing an audience.... The third is the voice of the poet when he attempts to create a dramatic character speaking in verse." Smith claims to be interested in only the first two voices, although in Chapter 4 we are told that "the sonnets are in some sense dramatic" and in Chapter 2, entitled "Personae," the "I" of the sonnets is called "a persona with identifiable traits" (p. 23) while the poems speak, "most of the time, to a persona... . But they are poems of the second voice, poems addressed to an audience of one or more, poems to be heard and mentally responded to" (p. 41). And it seems that the dramatic rather than the lyric poet is recalled in Smith's observation that "anything important, to be fully realized must be viewed both tragically and comically" (p. 109).

Chapter 3 discusses "The Poet \& the World," which is largely a courtly world, and Chapter 5 on "Order and Punctuation" rehearses and comments on the "rearrangers" of the sonnets such as J.D. Wilson (1968), T. Brooke (1936), and J.W. Lever (1956), as well as the dating of the sonnets by L. Hotson (1949) and the numerological studies by A. Fowler (1970). For Smith the theories of Laura Riding and Robert Graves (1927) are absurd, and Stephen Booth, who devotes five pages to summarizing their argument in his edition of the sonnets (1977) completely overlooks the fundamental fallacy of the Riding-Graves essay: "the punctuation of the sonnet in the quarto of 1609 is not the work of the poet, but of one of the two compositors in the workshop of Eld, the printer" (p. 125). Smith earlier admits a debt to Booth's commentary, yet seems to reject it because Booth "accepts completely William Empson's dictum that all suggested glosses for a passage are right" (p. x, and p. 11 n. 18). Smith admits a preference for I.A. 